\title{
Reconstruction of Proto-Kampa Verbal Morphology
}

\author{
Aimee Lawrence \\ University of Texas at Austin
}

\section{Introduction}

\subsection{Historical linguistics in the Amazon}

Detangling the complicated relationships among languages in the Amazon is complex. Epps (2009) advocates a fine-grained approach to establishing language relationships, pointing out that internal subgrouping and reconstruction of families is an important step toward understanding relationships among languages. However, the trend in the literature has been to suggest large-scale classifications. Furthermore, the lack of descriptive work on many languages creates an obstacle to doing much of the necessary historical work. ${ }^{1}$

This is especially true of the Arawak language family. Large-scale classifications of Arawak languages have been suggested, but these are often problematic. Matteson (1979) presents a reconstruction of Proto-Arawakan. However, this work is not built up from reconstructions of smaller groups. It also includes languages that have never been proven to be (and are generally believed not to be) related to the Arawak languages.

Payne (1991) presents an internal classification of Arawak languages, but includes only 24 languages in his sample and suggests subgroupings on the basis of shared retentions (rather than innovations). The paper notes that the methodology is less than ideal, saying "These reconstructions are to be considered as preliminary...a

1 Many thanks to Pattie Epps, Lev Michael, Nora England, the members of the UT MAL and LARGA research groups, and the BLS audience for their extensive comments on earlier drafts of this paper. Thanks also to Lev Michael for access to the data. All remaining errors are my own. 
more proper methodology would have been to reconstruct each subgroup and build successively backwards to the reconstruction of Proto-Maipuran [Proto-Arawak]. This task still remains to be done" (Payne 1991:356).

Aikhenvald (1999) directs the reader toward the major problems in Arawak historical linguistics research, saying "Though there are no doubts concerning the genetic affilation of the Arawak languages...problems still exist concerning internal genetic relationships within the family and possible genetic relationships with other groups" (Aikhenvald 1999:73). Da Silva Facundes (2002) notes the same issues with previous work on Arawak but attempts a move toward finer-grained classifications by presenting a preliminary reconstruction of the Piro-Apurinã-Iñapari branch.

One of the greatest stumbling blocks to earlier reconstruction attempts was a simple lack of data (Aikhenvald 1999). Since Payne (1991), the amount and quality of available descriptive work on Arawak languages (and Kampan languages specifically) has improved greatly. With respect to the Kampan languages discussed in this paper, scholars in the last ten years have produced a reference grammar of Ashéninka Perené (Mihas 2010) and a detailed sketch of Nanti (Michael 2008). Serious documentation projects have begun on Nomatsigenga, Matsigenka, and Kakinte.

In this paper, I adopt a fine-grained approach to reconstruction, reconstructing a number of verbal morphemes for the Kampan branch (a small branch of Arawak). In this paper, I intend to identify easily-reconstructable morphemes and suggest a preliminary path of development for morphemes that are less transparent. In the remainder of $\S 1$, I introduce the Kampan branch's internal groupings and phonology. In $\S 2$, I reconstruct the Kampan bound subject pronouns. In $\S 3$, I reconstruct object markers, followed by number marking in $\$ 4$, directionals in $\$ 5$, reality status markers in $\S 6$, and valence-changing morphology in $§ 7$. Finally, I revisit the topic of subgrouping within the Kampan branch in $\S 8$.

\subsection{Kampan languages}

Reconstructing the Kampan branch of Arawak is one step toward reconstruction of larger groups. The Kampan branch is comprised of six languages: Nanti, Matsigenka, Nomatsigenga, Kakinte, Ashéninka, and Asháninka. All of these languages are spoken in the Andean foothills and Amazonian areas areas of Peru, although some speakers of Ashéninka spill over into Brazil.

While it is clear that these languages do make up a subgroup of Arawak (Michael 2011), the exact makeup of the branch is not completely clear. Specifically, there are two plausible groupings, as shown in (1) and (2). 


\section{Reconstruction of Proto-Kampa Verbal Morphology}

(1)

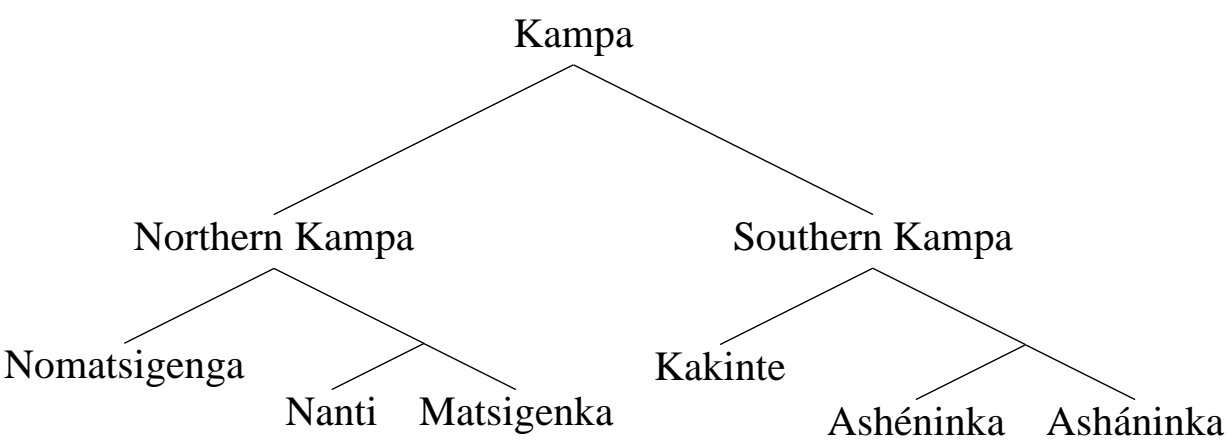

(2)

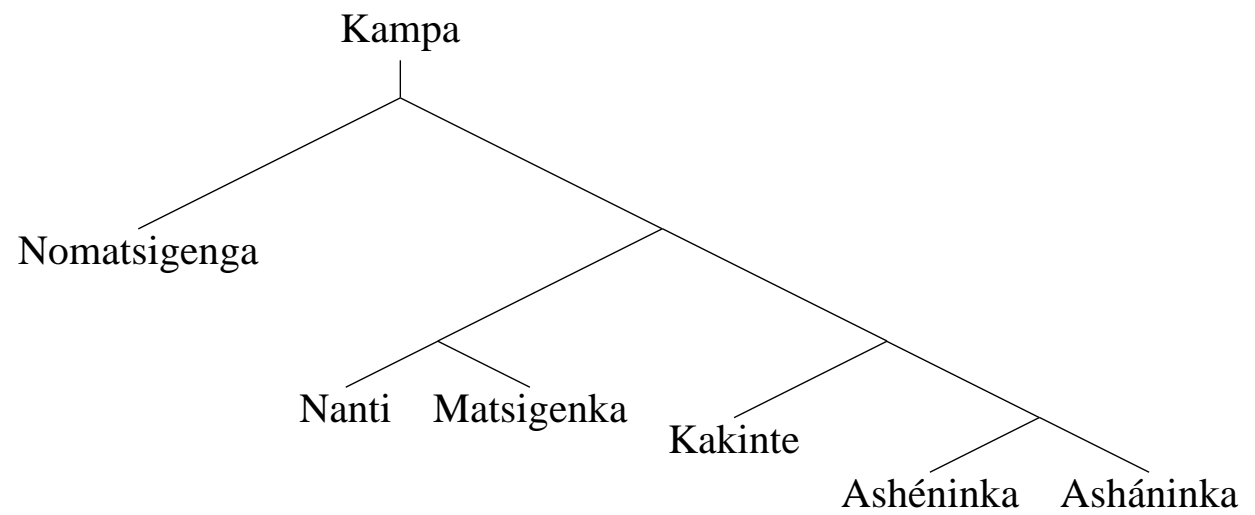

In (1), Proto-Kampa (henceforth PK) is assumed to have first split into a Northern Kampa and Southern Kampa subgroup, after which the Northern Kampa group was differentiated into Nomatsigenga, Matsigenka, and Nanti while Southern Kampa split into Kakinte, Ashéninka, and Asháninka. On the other hand, the tree in (2) assumes that Nomatsigenga split off from the rest of the group first, followed by a branch that subsequently broke into Matsigenka and Nanti, followed by Kakinte, followed by a final split between Asháninka and Ashéninka. Crucially, a choice between these two analyses requires a common innovation either among the languages in the 'Northern Kampa' branch-Nomatsigenga, Nanti, and Matsigenga (1), or among all of the languages but Nomatsigenga (2).

\subsection{Proto-Kampa phonology}

Michael (2011) presents a PK phonological reconsruction, which supports the analysis shown in (2) by demonstrating a sound change of $*_{s}>\int / \ldots i$ in Matsigenka, Nanti, Kakinte, Ashéninka and Asháninka (all languages but Nomatsigenga). However, a sound change of $*_{s}>\int$ is cross-linguistically quite common.

Michael (2011)'s phonological reconstruction demonstrates the regular sound changes in (3-10).

(3) $*_{s}>\int /$ _ i (Nanti, Matsigenka, Kakinte, Asháninka, Ashéninka)

(4) *ii >i (Kakinte, Asháninka, Ashéninka)

(5) $*$ s $>\int /$ _e (Kakinte, Asháninka, Ashéninka)

(6) $* g>\emptyset / V \_V$ (Asháninka, Ashéninka) 
Aimee Lawrence

\begin{tabular}{l|cccccc} 
Manner/Place & Bilabial & Dental & Alveopalatal & Velar & Glottal & Unspecified \\
\hline Stop & $* \mathrm{p} * \mathrm{~b}$ & $*_{\mathrm{t}}$ & & $*_{\mathrm{k}} *_{\mathrm{g}}$ & & \\
Fricative & & $*_{\mathrm{s}}$ & $* \int$ & & $* \mathrm{~h}$ & \\
Affricate & & $*_{\mathrm{ts}}$ & $* \mathrm{t} f$ & & & \\
Nasal & $* \mathrm{~m}$ & $*_{\mathrm{n}}$ & & & & $* \mathrm{~N}$ \\
Liquid & & & $*_{\mathrm{c}}$ & & & \\
Semivowel & & & $*_{\mathrm{j}}$ & & &
\end{tabular}

Table 0.1: Proto-Kampa Consonants

(7) *mp, * $\mathrm{yk}>\mathrm{m}, \mathrm{y}$ (Nomatsigenga)

(8) $* \mathrm{a}>\mathrm{o} / \_\mathrm{C}[+\mathrm{labial}]$ (Nomatsigenga)

(9) $* \mathrm{t}>\mathrm{ts} / \ldots \mathrm{i}$ (Ashéninka)

(10) $* \mathrm{ts}^{>} \mathrm{t}^{\mathrm{h}} / \ldots$ a, o (Ashéninka)

The consonant inventory of PK, as reconstructed by Michael (2011), is shown in Table 0.1, the vowels are shown in Table 0.2.

\begin{tabular}{l|ccc} 
& Front & Mid & Back \\
\hline High & $*_{\mathrm{i}}$ & $*_{\mathrm{i} i}$ & \\
Mid & $*_{\mathrm{e}}$ & & $*_{\mathrm{o}}$ \\
Low & & $*_{\mathrm{a}}$ &
\end{tabular}

Table 0.2: Proto-Kampa Vowels

In this paper, I suggest that there are two other common processes occurring sporadically that are important for reconstruction. These are $/ \mathrm{h} /$ deletion and the reanalysis of a morpheme-initial /a/ as epenthetic.

There are several morphemes discussed below for which I reconstruct a segment $/ \mathrm{h} /$ which is lost in the reflexes in the modern languages. There does not appear to be a regular environment for these deletions, nor do these changes appear to be the result of analogical change. However, Nomatsigenga, Nanti, and Kakinte both have synchronic processes of optional /h/ deletion (Michael 2008; Lawrence 2011; Swift 1988), as can be seen in the Nanti example in (11). This synchronic process may have provided a motivation for dropping the $/ \mathrm{h} /$ in these forms altogether ${ }^{2}$.

\section{(11) (Nanti) [pãho] [pão] 'gourd sp.' (Michael 2008:231)}

I also suggest a widespread process of reanalysis of /a/, in morpheme-initial position, as epenthetic or vice versa (an epenthetic /a/ reanalyzed as part of a morpheme). Verbs in Kampan languages are polysynthetic, and suffixing often results in illegal consonant or vowel clusters. Illegal clusters that follow the verb root are

${ }^{2}$ Some forms may also have been misanalyzed by researchers. 


\section{Reconstruction of Proto-Kampa Verbal Morphology}

resolved by epenthesis-epenthetic /a/ is used to break up consonant clusters, as shown in (12). I suggest that, as a result of this process, some suffixes with/a/ in initial position have been reanalyzed as a sequence of an epenthetic /a/ and a suffix, or vice versa. ${ }^{345}$

\section{(12) ikamAke (Nomatsigenga)}

$$
\begin{aligned}
& i=\quad k a m-k \quad-i \\
& 3 \mathrm{mS}=\text { die } \quad \text {-PERF }- \text { REAL.I }
\end{aligned}
$$

'He died.'

\subsection{Materials and Methodology}

Data comes from grammatical sketches, reference grammars, and my own field notes on Nomatsigenga. Data comes primarily from Shaver (1996) and Lawrence (2011) for Nomatsigenga; Michael (2008) for Nanti; Snell (1998) for Matsigenka; Swift (1988) for Kakinte; Kindberg (1975) for Asháninka; and Payne (1980) for Ashéninka.

\section{Subject Pronouns}

For verbs, I reconstruct five PK bound subject pronouns, which are shown in Table 0.3 , along with reflexes in the modern languages. Pre-vocalic variants are shown in parentheses.

\begin{tabular}{|l|l|l|l|l|l|}
\hline Language & 1 sg./pl excl. & 2 & 3 non-masc. & 3 masc. & 1 pl. incl. \\
\hline \hline Nomat. & $\mathrm{na}=/ \mathrm{no}=(\mathrm{n}=)$ & $\mathrm{pi}=(\mathrm{p}=)$ & $\mathrm{o}=(\mathrm{p}=)$ & $\mathrm{i}=(\mathrm{y}=)$ & $\mathrm{a}=/ \mathrm{o}=)$ \\
Matsi. & $\mathrm{no}=(\mathrm{n}=)$ & $\mathrm{pi}=(\mathrm{p}=)$ & $\mathrm{o}=$ & $\mathrm{i}=(\mathrm{y}=)$ & $\mathrm{a}=$ \\
Nanti & $\mathrm{no}=(\mathrm{n}=)$ & $\mathrm{pi}=(\mathrm{p}=)$ & $\mathrm{o}=$ & $\mathrm{i}=(\mathrm{y}=)$ & $\mathrm{a}=$ \\
Kakinte & $\mathrm{no}=(\mathrm{n}=)$ & $\mathrm{pi}=(\mathrm{p}=)$ & $\mathrm{o}=$ & $\mathrm{i}=(\mathrm{y}=)$ & $\mathrm{a}=$ \\
Asháninka & $\mathrm{no}=(\mathrm{n}=)$ & $\mathrm{pi}=(\mathrm{p}=)$ & $\mathrm{o}=$ & $\mathrm{i}=(\mathrm{y}=)$ & $\mathrm{a}=$ \\
Ashéninka & $\mathrm{no}=(\mathrm{n}=)$ & $\mathrm{pi}=(\mathrm{p}=)$ & $\mathrm{o}=$ & $\mathrm{i}=(\mathrm{y}=)$ & $\mathrm{a}=$ \\
\hline \hline PK & ${ }^{*} \mathrm{no}=\left({ }^{*} \mathrm{n}=\right)$ & $* \mathrm{pi}=(* \mathrm{p}=)$ & ${ }^{*} \mathrm{O}=\left({ }^{*} \mathrm{w}=\right)$ & $* \mathrm{i}=\left({ }^{*} \mathrm{y}=\right)$ & $* \mathrm{a}=$ \\
\hline
\end{tabular}

Table 0.3: Proto-Kampa A/Sa proclitics

\footnotetext{
${ }^{3}$ Here and elsewhere, epenthetic segments are shown in the first line of a gloss using an uppercase A or T. Other characters are IPA equivalent, except $r$, which represents / $\mathrm{f} /$ and $N$, representing a nasal not specified for place of articulation.

4 glossing conventions are as follows: 1ss first-person sing./pl. excl. subject; 3mo third-person masculine object; $3 \mathrm{~ms}$ third-person masculine subject; $3 \mathrm{nms}$ third-person non-masculine subject; IMP imperfective; IRREAL irrealis; PERF perfective; PL plural; REAL.I realis, class 'I' verb

${ }^{5}$ It should also be noted that, in some cases, the source for data may contain errors in morphological segmentation. For all morphemes, I use the form listed in the relevant source for the language, except where I have data for Nomatsigenga.
} 
Aimee Lawrence

\subsection{Alignment in Proto-Kampa}

Most Kampan languages are primarily nominative-accusative languages, although some also show traces of other alignment patterns. Ashéninka has a split intransitive pattern (Mihas 2010; Payne and Payne 2005). Nanti also has traces of fluid-S alignment (Michael 2008). It is beyond the scope of this paper to reconstruct PK's exact alignment system. However, as noted by Nichols (2003), ergativity is a relatively "recessive" feature. While it is not clear whether the same is true of split or pragmatic systems such as have been described for Kampan languages, I assume that Proto-Kampa was not a completely nominative-accusative language, but that accusative patterns have arisen in some languages.

\subsection{First-person singular/plural exclusive subject}

For the first-person singular/plural exclusive bound subject marker, I reconstruct a Proto-Kampa form *no=. Nanti, Matsigenka, Kakinte, Asháninka, and Ashéninka all have the basic form $n o=$, while Nomatsigenga has the allomorphic distribution shown in (13).

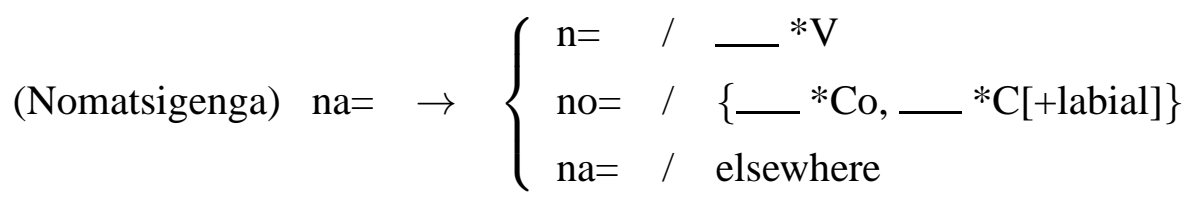

I suggest that this distribution in Nomatsigenga was created first from a levelling of the subject and object markers (the first-person singular/plural exclusive marker is - $n a$ in all the Kampan languages), so that Nomatsigenga then used the subject marker $n a=$. Nomatsigenga also underwent a general sound change in which $/{ }^{*} \mathrm{a} /$ became $/ \mathrm{o} /$ before labials (8), a process which created the allomorph $n o=$ before bilabials. However, the origins of the vowel-harmony rule for this morpheme are unclear. While this may suggest that the PK form should be *na=, with a vowel harmony rule to create $* n o=$ (under this analysis the $\mathrm{PK} *_{n} o=$ variant then spread to be used with all verb roots in the other five languages), there is no other evidence to suggest that the vowel-harmony variant existed in Proto-Kampa. Further, some Arawak languages believed to be closely related to the Kampan languages have the first-person variant $n o=$, as in the case of Piro (Matteson 1965).

On the other hand, there is an additional piece of evidence for suggesting that the $n a=$ form is older than the $n o=$ form in the Kampan languages. This evidence comes from some archaic forms from Nanti. In the Kampan languages, verbal subject markers and possessive markers on nouns have both the same basic form and the same allomorphic rules. Since this is true of all the Kampan languages, I suggest that PK must also have used the same markers for verbal subjects and to mark possession. Some Nanti noun stems require an irregular $n a$ - form to mark a first-person singular possessor, as shown in (14). Such forms could be evidence to suggest that $n a$ - is an older form. However, this morpheme could be the reflex of something that was archaic even in Proto-Kampa. 


\section{Reconstruction of Proto-Kampa Verbal Morphology}

\section{(14) (Nanti) naneni}

na- neni

$1 \mathrm{sS}-$ space

'the space at my side'

\subsection{Third-person non-masculine}

I suggest that the Proto-Kampa third-person non-masculine is $*_{o=}$ with the allomorph $*_{w}=$. Nanti, Matsigenka, Kakinte, Asháninka, and Ashéninka use $o=$ for third-person non-masculine subject and possessor. With vowel-initial stems, vowel hiatus is resolved by deleting the $o=$, as shown in (15), from Nanti.

(15) Aratehanake. (Nanti)

$$
\begin{aligned}
& o=\text { arateh }- \text { an }-a k \quad-i \\
& \text { 3nms wade }-\mathrm{ABL}-\mathrm{PERF}-\mathrm{REAL} . \mathrm{I}
\end{aligned}
$$

'She waded away.' (Michael 2008:269)

Nomatsigenga also has $o=$ to indicate a third-person non-masculine subject, but it uses the allomorph $p=$ before vowel-intial stems, such as in example (16).

$$
\text { pisamini (Nomatsigenga) }
$$

$$
\begin{array}{ll}
p=\quad \text { isam }-i & =n i \\
3 \mathrm{nmS}=\text { sleep }- \text { REAL.I } & =\text { IMP.A }
\end{array}
$$

'She is sleeping.'

I suggest that Proto-Kampa's third-person non-masculine marker was $*_{o=}=$ with $*_{w}=$ as a pre-vocalic allomorph, which was lost in all the languages but Nomatsigenga, where $*_{w}=>p=$. This is certainly a surprising sound change (which is problematic for the analysis). However, this change does have the phonetic advantage of creating a larger sonority difference between the onset and nucleus of the word-initial syllable and analogy with the second-person subject marker $p i=$ may have also helped to drive the change.

Reconstructing $*_{w}=$ as an allomorph of $*_{o}=$ also has the advantage of reconstructing symmetry in the third-person pronouns, with vowels $\left(*_{i=}{ }^{*} o=\right)$ used with consonant-initial roots and glides $*_{j}=, *_{w}=$, used with vowel-initial roots. No phoneme /w/ is reconstructed for PK. However, Nomatsigenga, which also doesn't have a phoneme $/ \mathrm{w} /$, does have a process that changes some morpheme-final [o] to [w] before vowels, suggesting that there may be an analogous process in PK. Further, a similar allomorphy pattern to the one reconstructed here for PK is found in Apurinã. Apurinã, which is fairly closely related to the Kampan branch, has the third-person feminine subject marker $o$-. Before vowel-initial forms, $o^{w}$ - is sometimes used. Before stems beginning with $/ \mathrm{h} /, \tilde{o}^{w}$ is always used, as in (17). 
Aimee Lawrence

(17)

\section{$\tilde{o}^{w}-\tilde{e} n \tilde{e} m a$}

3nms-saliva

'her saliva' (Da Silva Facundes 2002:149)

\subsection{Second Person, third-person masculine, first-person plural inclusive}

The second-person and third-person masculine subject markers seem to be unproblematic, since all the languages use the same forms and the same pre-vocalic variants. Therefore, I reconstruct the basic form *pi= and the pre-vocalic allomorph ${ }^{*} p=$ before vowels for the PK second-person subject marker. Similarly, I reconstruct $* i=$ with a pre-vocalic allomorph $* j=$ for the PK third-person masculine subject marker. I reconstruct the first-person plural inclusive marker as $* a=$, since this morpheme is $a=$ in all the Kampan languages, except Nomatsigenga, where it is $o=$ before bilabial consonants. I suggest that the Nomatsigenga allomorphy stems from the regular sound change shown in (8).

\section{Object Marking}

\begin{tabular}{|c|c|c|c|c|c|}
\hline Language & $1 \mathrm{sg} . / \mathrm{pl}$. excl. & 2 & 3 non-masc. & 3 masc. & 1 pl. incl. \\
\hline Nomat. & $-n a$ & $-\mathrm{mi}$ & -ro & -ri & 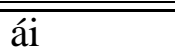 \\
\hline Matsi. & - na & -mpi & -ro & $-\mathrm{ri}$ & $-a i /-a e$ \\
\hline Nanti & $-n a$ & -mpi & -ro & -ri & - \\
\hline Kakinte & -na & - mpi & -ro & -ri & -ahi \\
\hline Asháninka & - na & -mpi & -ro & -ri & - na \\
\hline Ashéninka & - na & $-\mathrm{mi}$ & -ro & -ri & $-\mathrm{ai}$ \\
\hline$\overline{\mathrm{PK}}$ & *-na & *-mpi & *-ro & *-ri & *-ahi \\
\hline
\end{tabular}

Table 0.4: Proto-Kampa object markers

\subsection{Second-person object}

I reconstruct *-mpi, based on the form found in most of the languages. In Nomatsigenga, the form is reduced to *-mi, which is expected based on sound change (7) (sequences of labial or velar nasals and stops are reduced to a homorganic nasal). Ashéninka has also reduced the form to *-mi, which is not expected based on sound changes. However, there seems to be substantial contact between Nomatsigenga and Ashéninka, suggesting that the Ashéninka morpheme may be a borrowing.

\subsection{First-person singular/plural inclusive $\&$ third person}

The form of the first-person singular/plural exclusive is - $n a$ in all extant Kampan languages, leading me to reconstruct *-na for this morpheme. Similarly, the marker for third-person non-masculine objects is -ro in all Kampan languages. Therefore, I reconstruct *-ro for this morpheme. Similarly, I reconstruct *-ri as the third-person 


\section{Reconstruction of Proto-Kampa Verbal Morphology}

masculine object marker, since the reflexes have the same phonological form in all the Kampan languages.

\subsection{First-person plural inclusive}

I reconstruct $*_{\text {-ahi }}$ as a first-person plural inclusive marker. This morpheme has been lost entirely in Nanti, where a free pronoun is used for this purpose. In Asháninka, this morpheme has also been lost, with the use of the first-person singular bound pronoun extended for all first-person reference. The reflex of this form remains in Kakinte, Ashéninka, Nomatsigenga, and Matsigenka. Kakinte retains the form $=a h i$, while both Ashéninka and Nomatsigenga have lost the medial $/ \mathrm{h} /$ (causing high tone in Nomatsigenga). The loss of $/ \mathrm{h} /$ is a relatively common sound change, meaning that these could be independent innovations in both languages. On the other hand, the Ashéninka form could be borrowed from Nomatsigenga, as was also suggested with the second-person object marker.

The Matsigenka marker presents another challenge. Snell (1998) lists the marker as $-a i$ in realis clauses and - $a e$ in irrealis clauses. In Matsigenka and other Kampan languages, $-i$ is a realis suffix, and $-e$ is an irrealis suffix, suggesting that the first-person plural marker and the reality status markers have been fused. These reality status suffix precede object-markers in other Kampan languages, but given that the use of the first-person plural object marker causes the reality status markers to delete in some other Kampan languages (e.g. Nomatsigenga), the sequence $a i$ could have been reanalyzed as a sequence of a person marker and a reality status marker.

\section{Number Marking}

Proto-Kampa had plural, distributive, and partitive markers, which are shown in 0.5 .

\begin{tabular}{|l|l|l|l|l|l|l|l|}
\hline Number & Nomat. & Nanti & Matsi. & Kakinte & Ashá. & Ashé. & PK \\
\hline \hline Plural & -hig & -hig & -(a)ig & -hi(g) & -hei & -aij/-he & $*$-hig \\
Distributive & -ge & -ge & -ge & - & -je & -je & $*$-ge \\
Partitive & -garant & - & agarant & -garant & -aarant & - & $*_{\text {-garant }}$ \\
\hline
\end{tabular}

Table 0.5: Number Marking

\subsection{Plural}

The plural is a verbal morpheme that can make either the subject or object referent plural. I reconstruct *-hig for this morpheme, with the $/ \mathrm{h} /$ lost in Matsigenka. The loss of the $/ \mathrm{g} /$ in Ashéninka and Asháninka is predictable from the regular loss of $\mathrm{g} /$ intervocalically in those languages. It is unclear what process would lead to the loss of the final /g/ of the Kakinte morpheme, but it seems clear that this /g/ could not have been an innovation in the other languages. 
In Ashéninka, there is both a plural suffix -he and a discontinuous plural marker made up of either -he or -aij ('aiy') plus the suffix -ni. The -ni may be historically related to a morpheme - $n i$ which is used synchronically in Ashéninka Perené and Kakinte as an augmentative (Mihas 2010; Swift 1988) and as a 'durative extremal' in Matsigenka (Michael p.c.). The -he portion of the morpheme seems to be the reflex of Proto-Kampa *-hig. Since Ashéninka underwent a process in which intervocalic /g/ was lost (6), and this morpheme appears word-medially, the loss of the $/ \mathrm{g} /$ is explicable, although the change in vowel quality is unexpected.

\subsection{Distributive}

I reconstruct $*_{-}$ge as a distributive, which has the meaning that the action described by the verb stem was carried out several times in different locations. This morpheme was lost in Kakinte, although a non-cognate morpheme has a similar purpose. The Asháninka and Ashéninka forms are both -je. These two languages deleted intervocalic /g/ (6). The /j/ in these forms (and in the Ashéninka plural -aij) may have developed in order to break up vowel sequences. Although an epenthetic $/ t /$ is normally inserted when there are illegal clusters of vowels in verbs in Kampan languages, the forms would originally have had an initial consonant, perhaps blocking / $\mathrm{t} /$-epenthesis.

\subsection{Partitive}

I suggest the reconstructed form *-garant. In Asháninka, the /g/was lost intervocalically, as expected from (6), and in both Matsigenka and Asháninka the preceding epenthetic /a/ was reanalyzed as part of the morpheme. The form was lost in Nanti and Ashéninka.

\section{Directionals}

Proto-Kampa had allative and ablative verb markers, as well as a marker that had a meaning that the action was "goal-oriented." These markers are shown in 0.6.

\begin{tabular}{|l|l|l|l|l|l|l|l|}
\hline Directional & Nomat. & Nanti & Matsi. & Kakinte & Ashá. & Ashé. & PK \\
\hline \hline Allative & -an & -an & -an & -an & -an & -an & *an $_{\text {-an }}$ \\
Ablative & -apa & -apah & -apa & -apoh & -apaa & -apag & *apah $_{\text {apa }}$ \\
Receptive & -ab & -ab & -ab & -ab & -ab & -ab & *ab $_{-a b}$ \\
\hline
\end{tabular}

Table 0.6: Kampa Directionals

\subsection{Ablative}

I reconstruct *-apah, suggesting that the /h/ was lost in Nomatsigenga, Matsigenka, and Asháninka, but maintained in Nanti. In Asháninka, the morpheme has a long vowel /aa/, which could be the result of losing the morpheme-final $/ \mathrm{h} /$ and reinterpreting a following epenthetic /a/ as part of the morpheme. 


\section{Reconstruction of Proto-Kampa Verbal Morphology}

However, Ashéninka has a /g/ morpheme-finally, which is problematic since it requires that $/ * \mathrm{~h} />/ \mathrm{g} /$. - apag only seems to be found in one variety of Ashéninka (Payne 1980), other varieties have -ap (Mihas 2010). The form -apag may have been created on analogy with the causative -akag in this variety. Although this analysis may be problematic, it seems similarly troublesome to suggest that the reconstructed form should be *apag. From what has been proven with respect to the internal subgrouping of Kampa, this would have to have occurred independently at least three times, in the Northern Kampa group (assuming such a group exists), in Kakinte, and in Asháninka. While this sound change isn't unlikely, the independent innovation multiple times in this group does seem unlikely.

\section{Reality Status}

All six languages have realis and irrealis markers, which are fused with verb class markers. Realis clauses use a suffix (differentiated for verb class), while irrealis clauses use a prefix (the same for all verbs) and a suffix (differentiated for verb class). The Nomatsigenga forms are shown in Table 0.7. The markers for all the languages are shown in Table 0.8 .

\begin{tabular}{|l||l|l|}
\hline & Class I & Class A \\
\hline Realis & $-\mathrm{i}$ & $-\mathrm{a}$ \\
Irrealis & $\mathrm{N}-\mathrm{-e}$ & $\mathrm{N}-$-ima \\
\hline
\end{tabular}

Table 0.7: Nomatsigenga Reality Status Markers

\begin{tabular}{|l|l|l|l|l|l|l|l|}
\hline & Nomat. & Nanti & Matsi. & Kakinte & Ashá. & Ashé. & PK \\
\hline \hline Irreal. prefix & N- (r-) & N- (r-) & N- (r-) & N- (r-) & N- (r-) & N- (r-) & $*$ N- (*r-) \\
Realis I & $-\mathrm{i}$ & $-\mathrm{i}$ & $-\mathrm{i}$ & $-\mathrm{i}$ & $-\mathrm{i}$ & $-\mathrm{i}$ & $*_{-} \mathrm{i}$ \\
Realis A & $-\mathrm{a}$ & $-\mathrm{a}$ & $-\mathrm{a}$ & $-\mathrm{a}$ & $-\mathrm{a}$ & $-\mathrm{a}$ & $*_{-} \mathrm{a}$ \\
Irrealis I & $-\mathrm{e}$ & $-\mathrm{e}$ & $-\mathrm{e}$ & $-\mathrm{e}$ & $-\mathrm{e}$ & $-\mathrm{i} /-\mathrm{e}$ & $*_{-} \mathrm{e}$ \\
Irrealis A & $-\mathrm{ima}$ & $-\mathrm{empa}$ & - empa & -empa & -empa & -ia/-ea & $*_{\text {empa }}$ \\
\hline
\end{tabular}

Table 0.8: Kampan reality status markers

\subsection{Irrealis prefix}

The irrealis prefix is $N$ - for all languages. This morpheme and the phoneme $/ \mathrm{N} /$ appear only syllable-finally before a stop consonant, as shown in example (18). Before a vowel or a non-stop consonant, as in example (19), the morpheme doesn't have an overt realization. All the languages have an allomorph $r$-for the irrealis prefix, used with vowel-initial verb stems with a third-person masculine subject marker. I reconstruct this process for PK as well.

ompatuije (Nanti) 
Aimee Lawrence

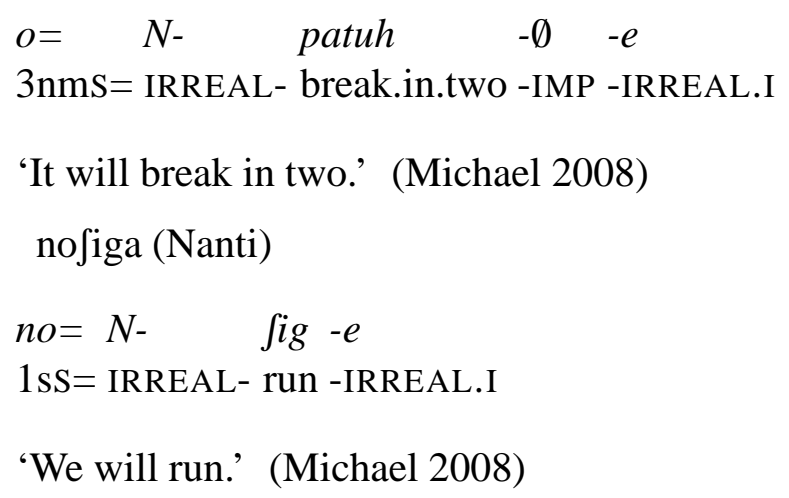

'We will run.' (Michael 2008)

This process is the same in all languages, except Nomatsigenga. In Nomatsigenga, sequences of $* \mathrm{~Np}[\mathrm{mp}]$ or $* \mathrm{Nk}[\mathrm{gk}]$ were collapsed to [m] and [n], respectively (sound change 7). With Nomatsigenga verb stems that begin in $/ \mathrm{p} /$ and $/ \mathrm{k} /$, the irrealis prefix surfaces as a homorganic nasal replacing the stop, as shown in example (20).

(20) nomiini

$$
\begin{aligned}
& n o=N-\quad p-e \quad=n i \\
& 1 \mathrm{~S}=\text { IRREAL- eat }- \text { IRREAL.I }=\text { IMP.A } \\
& \text { 'I will eat.' }
\end{aligned}
$$

\subsection{Realis suffixes}

In all the Kampan languages, there is a class I realis marker $-i$ and a class A realis marker $-a$. I reconstruct these markers as $*_{-i}$ and $*_{-} a$.

\subsection{Class I irrealis suffix}

I reconstruct $*_{-} e$ for the class I irrealis suffix, since all languages have the form - $e$ except in Ashéninka, it is sometimes - $i$. The Ashéninka form may possibly be due to collapse with the class I realis form and facilitated by the fact that irrealis mood is also marked with a prefix. There are some contexts, notably after the perfective suffix - ak in most of the Kampan languages where the class I realis (-i) and irrealis $(-e)$ suffixes are neutralized.

\subsection{Class A irrealis suffix}

The form of the class A irrealis suffix is -eNpa ([-empa]) in Nanti, Matsigenka, Kakinte, and Asháninka. The Nomatsigenga form, -ima is partly predictable based on the reduction of sequences of [mp] to [m] (7). I further suggest that the shift in the initial vowel of the suffix was created by analogy with the class I realis suffix. For the Ashéninka form, I suggest that the neutralization of /i/ and /e/ in some contexts for the class I irrealis suffix has led to some reanalysis of the initial vowel (similar to the suggestion for the Class I irrealis suffix). 


\section{Reconstruction of Proto-Kampa Verbal Morphology}

\section{Valence-changing inflectional morphology}

PK has a number of causative and applicative affixes, as shown in Table (0.9).

\begin{tabular}{|c|c|c|c|c|c|c|c|}
\hline & Nomat. & Nanti & Matsi. & Kak. & Ashá. & Ashé. & PK \\
\hline Agent caus & ogi- & ogi- & ogi- & - & oi- & - & $*_{\text {ogi }}$ \\
\hline Non-agent & o[+voi $]-$ & o[+voi]- & $\mathrm{o}[+\mathrm{voi}]-$ & - & - & - & $*_{0-/} * \emptyset$ \\
\hline Malefact. & omí- & omiN- & om(in)- & - & omiN- & - & *omiN- \\
\hline Influential & $-k a g$ & -akag & -(ak)ag & -akag & -akaa & -akag & $*_{\text {-akag }}$ \\
\hline Instrument. & -ant & -ant & -ant & -ant & -ant & - & $*_{\text {-ant }}$ \\
\hline Presential & $-\mathrm{mo}$ & -imo & -imo & -imo & -imo & -imo & *-imo \\
\hline Separative & -pi & -apitsa & -apitsa & 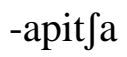 & -apitsa & - pit $^{\mathrm{h}} \mathrm{a}$ & *-apitsa \\
\hline Purposive & $-s i$ & $-a \int i$ & $-a \int i$ & $-a \int i$ & $-a \int i$ & $-a \int i$ & $*_{\text {-asi }}$ \\
\hline
\end{tabular}

Table 0.9: Kampa valence-changing morphology

\subsection{Agentive causative}

I reconstruct a morpheme *ogi-, which is the form in most of the languages with a reflex of this morpheme. In Ashéninka, the form is oi-. This is the expected form considering the regular loss of intervocalic /g/ (6).

\subsection{Non-agentive causative}

There are three languages with a reflex of this morpheme-Nomatsigenga, Nanti, and Matsigenka. This is a possible subgroup of Kampa (see 1), Therefore, this may an innovation in a subgroup or a feature that lost in the Kakinte-AsháninkaAshéninka subgroup. I reconstruct a form $*_{o}$ [+voice], (adding a [+voice] feature to the first segment of the stem), but whether this is a PK form or a form reconstructable only to a Proto-Nomatisgenga-Asháninka-Ashéninka branch is unclear.

\subsection{Malefactive causative}

I reconstruct a Proto-Kampa form *omiN-, which is retained in Nanti and Asháninka, and possibly in Matsigenka, which has the allomorphs omin-/om-, but the conditioning environments are unclear. In Nomatsigenga, the /N/ has been lost, possibly causing high tone on the preceding /i/ (omí). The morpheme was lost in Ashéninka and Asháninka.

\subsection{Influential}

I reconstruct the form *-akag, suggesting that the first /a/ was reanalyzed as epenthetic in Nomatsigenga. In Asháninka, the /g/ was lost, predictable from the regular loss of $/ \mathrm{g} /$ intervocalically (6) (this morpheme is word-medial, there is always a following vowel). However, it is unclear why the cognate form in Ashéninka, which also 
Aimee Lawrence

underwent this sound change, did not lose the /g/. Finally, Matsigenka shortens the form to $-a g$ in some contexts, although it's unclear which.

\subsection{Presential}

All the languages have a presential applicative, which I reconstruct in $\mathrm{PK}$ as *-imo, which is maintained in most of the languages, but Nomatsigenga has a reduced form, $-m o$.

\subsection{Separative}

There is a separative applicative form that reconstructs to *-apitsa. Nanti, Matsigenka, and Ashéninka all have -apitsa as the reflex of this form. Ashéninka has - apit $^{\mathrm{h}} a$, which is expected based on sound change (10). Nomatsigenga has a morpheme that may be cognate, although, if so, it has undergone significant reduction to - $p i$ via the reanalysis of initial /a/ as epenthetic. The loss of the final syllable of the morpheme, /tsa/, is more opaque.

\subsection{Purposive}

All six Kampan languages have a reflex of this form, which I reconstruct as *-asi. Nomatsigenga has reanalyzed the /a/, originally the first segment of the morpheme, as an epenthetic segment. In the other five languages the morpheme has become $-a \int i$, as expected from sound change in (3).

\section{Subgrouping}

The morphological reconstruction provides slight evidence for either of the subgroupings suggested in (2). Specifically, the innovation of the third-person nonmasculine subject marker, shown below in (21) makes a case for (2). However, this reconstruction is far from unproblematic, suggesting that this subgrouping has yet to be conclusively proven. Further, as noted by Nichols (2003), pronouns are relatively unstable and subject to change on the basis of leveling and analogy-therefore, perhaps not the best pieces of evidence to use to prove subgrouping.

$$
\begin{array}{rll}
*_{\mathrm{O}=} / *^{*} \mathrm{w}= & >\mathrm{o}=/ \mathrm{p}= & \text { (Nomatsigenga) } \\
& >\mathrm{o}= & \text { (Matsigenka, Nanti, Kakinte, Asháninka, Ashéninka) }
\end{array}
$$

\section{References}

Aikhenvald, Alexandra, 1999. The Arawak language family. In R. M. W Dixon and Alexandra Aikhenvald, eds., The Amazonian languages, 65-106. Cambridge: Cambridge University Press.

Da Silva Facundes, Sidney, 2002. Historical linguistics and its contribution to improving knowledge of Arawak. In Jonathan D. Hill and Fernando Santos- 


\section{Reconstruction of Proto-Kampa Verbal Morphology}

Granero, eds., Comparative Arawakan histories. Chicago: University of Illinois Press.

Epps, Patience, 2009. Language Classification, Language Contact, and Amazonian Prehistory. Language and Linguistics Compass 3(2):581-606.

Kindberg, William, 1975. Los morfemas verbales del Campa Asháninca. In Datos Etno-Linüísticos 11. Number 11 in Datos Etno-Linüísticos, Lima, Peru: Instituto Lingüístico del Verano.

Lawrence, Aimee L., 2011. Nomatsigenga field notes. Unpublished field materials.

Matteson, Esther, 1965. The Piro (Arawakan) language. Berkeley, California: University of California Press.

Matteson, Esther, 1979. Proto-Arawakan. In Esther Matteson, ed., Comparative studies in amerindian languages. The Hague: Mouton.

Michael, Lev D., 2008. Nanti evidential practice: Language, knowledge, and social action in an Amazonian society. Ph.D. thesis, University of Texas at Austin.

Michael, Lev D., 2011. La reconstrucción y la clasificación interna de la rama Kampa de la familia Arawak. In CILLA V.

Mihas, Elena, 2010. Essentials of Ashéninka Perené grammar. Ph.D. thesis, The University of Wisconsin-Milwaukee.

Nichols, Johanna, 2003. Diversity and stability in language. In Brian D. Joseph and Richard D. Janda, eds., The handbook of historical linguistics, chapter 5, 283-310. Malden, MA: Blackwell Publishing.

Payne, David L., 1980. Dicionario Ashéninca-Castellano. Number 18 in Documento de trabajo, Yarinacocha: Insituto Lingüístico de Verano.

Payne, David L., 1991. A Classification of Maipuran languages based on shared lexical retentions. In Desmond C. Derbyshire and Geoffrey K. Pullum, eds., Handbook of Amazonian languages, volume 3. New York: Mouton de Gruyter.

Payne, Judith K. and Payne, David L., 2005. The pragmatics of split intransitivity in Ashéninka. Revista Latinoamericana de Estudios Etnolingüísticos 10:37-55.

Shaver, Harold, 1996. Diccionario Nomatsiguenga-Castellano. Number 41 in Serie Lingüistica Peruana, Lima, Peru: Instituto Lingüístico del Verano.

Snell, Betty, 1998. Pequeño diccionario Machiguenga-Castellano. Number 32 in Documento de trabajo, Lima, Peru: Instituto Lingüístico del Verano.

Swift, Kenneth E., 1988. Morfología del Caquinte. Number 25 in Serie Lingüistica Peruana, Lima, Peru: Instituto Lingüístico del Verano.

Aimee Lawrence

Department of Linguistics

University of Texas at Austin

Mailcode B5100

Austin, TX 78712

aimee.lawrence@utexas.edu 